\title{
The Changing Notions of Political Economy in Greece Till the Beginning of the $21^{\text {St }}$ Century
}

\author{
Stavros D. Mavroudeas ${ }^{1}$
}

\begin{abstract}
This paper surveys the changing notions ascribed to the term 'Political Economy' in Greece from the beginning of the Greek economics till the beginning of the 21 st century. It relates them to the evolution of economic thought in Greece and the turbulent course of Greek capitalism. It argues that during the birth period of economic studies in Greece the term 'Political Economy' was identified with economic theory in general. covered the Classical Political Economy but with noteworthy influences from the German Historical School. From the end of the 2nd World War and afterwards, the identification of Political Economy with general economic theory was kept but the latter tended to be almost purely neoclassical. After 1974 the term was redefined and took its proper meaning, namely that of the scientific traditions that focus on the social nature of economic relations.
\end{abstract}

Keywords: Political Economy, Greece, Economic Thought

1 Dept. of Social Policy Panteion University, s.mavroudeas@panteion.gr,

https://orcid.org/0000-0003-2230-7479

DOI: 10.17932/IAU.FCPE.2015.010/fcpe_v06i2001 


\section{INTRODUCTION}

Political Economy (as distinct from Economics) is the first version of an autonomous science of economic relations. In the form of Classical Political Economy (more prominently represented by A. Smith and D. Ricardo) it had created the science of economic relations. Political Economy considers the economy as a 'social game', that is as a function of society having social character. This means that (a) its main agents are social classes, (b) a main process is the struggle between them and (c) the economy is intrinsically linked to the other social functions (politics etc.). Classical Political Economy was instrumental in aiding the establishment of the capitalist system during its struggle against the ancient regime. However, once the capitalist system was established and its own contradictions and failings emerged (especially in the form of recurrent economic crises and immiseration of the working class), the Classical Political Economy fell from grace. Economics - engineered by the Marginalist school - argued that the economy is a non-social 'individualist game'. This means that (a) the main agents are egoistic individual, (b) social groupings do not matter in the economy and (c) the economy is not related - at least intrinsically to the other functions of society. Economics became the new mainstream as they served better the capitalist system. On the other hand - and at the same time (end of $19^{\text {th }}$ century) - Marxist Political Economy emerged. The latter followed the same basic tenets with Classical Political Economy about the social character of the economy. But disagreed over the fate of capitalism by arguing that capitalism is not 'the end of history' (as the Classical Political Economy maintained) and that social evolution can surpass it by creating, through working class' struggle, a novel and more just socio-economic system (socialism). Economics became the mainstream approach to analyzing the economy whereas Marxist Political Economy dominated the underworld of Political Economy.

This paper surveys the changing notions that have been ascribed to the term 'Political Economy' in Greece from the beginning of the Greek economics till the beginning of the $21^{\text {st }}$ century. These notions are closely related to the evolution of economic thought in Greece and the debates between various economic approaches but also to the turbulent and marred by crises course of Greek capitalism. Moreover, these different understandings shaped 
crucially the academic landscape of Economics in Greece. In a nutshell, it is argued that during the birth period of economic studies in Greece the term 'Political Economy' was identified with economic theory in general. As such it covered the Classical Political Economy but with noteworthy influences from the German Historical School. Later, especially from the end of the 2nd World War and afterwards, the identification of Political Economy with general economic theory was kept but the latter tended to be almost purely neoclassical. Thus, the term was used as a corollary for neoclassical general economic theory and had nothing to do with Political Economy as such. After 1974 the term was redefined and took its proper meaning, namely that of the scientific traditions that focus on the social nature of economic relations and proceed to study them accordingly. This definition has predominated till today with only minor and unsuccessful attempts by neoclassicism to make inroads in the field through the socalled New Political Economy and Public Choice theory.

The main theme of the paper is supplemented by a survey of the status of Political Economy in the academic syllabi and in the teaching programs of the secondary education. It is being shown that its status follows, sometimes with a time lag, the changing conceptions of Political Economy.

\section{THE CHANGING NOTIONS of POLITICAL ECONOMY in GREECE}

The introduction of economic science in the Greek academic system has followed a rather peculiar trajectory; at least compared to the nowadays dominant Anglo-Saxon paradigm. This peculiar trajectory is closely related to Political Economy and the meaning that was attributed to $\mathrm{it}^{2}$. Three are the major differentiae specific of this trajectory.

First, economic science was introduced in the Greek university rather lately comparing with more advanced capitalist countries. Schumpeter (1954), surveying the history of economic analysis from 1790 till 1870 argues that a rapid professionalization took place during that period. Comparing tothat it was only in 1839 that the term 'economist' was firstly introduced

2 Psalidopoulos (1999) provides a very illuminating picture of this peculiar trajectory and the national specificities that characterized it for a significant period. 
win Greece (Psalidopoulos (1999), p.78). And it was only in 1837 that the study of economic science was introduced in the Greek universities with the creation of a chair on Plutology occupied by I. Soutsos in the Law School of the University of Athens. A second chair on Public Economics followed in 1881 but very soon became inactive. Afterwards, several chairs on economics were inaugurated - both in the National Kapodistriakon University of Athens and the Aristotelian University of Thessaloniki (which are the oldest Greek universities) - but always within the auspices of the Law School. After a period, several professional non-university schools were created which provided mainly vocational education that had to do with economics. These schools were dominated to a great extent by university professors, as they seldom held chairs also in these schools besides their universities.

A second feature has already been mentioned. Contrary to the usual AngloSaxon experience, university economics sprang out of law schools rather than philosophy schools Psalidopoulos (1999: 172-3). Indeed, from 1926 till 1967 economics were part of the syllabus of the Law School of the University of Athens and were separated only on the last $4^{\text {th }}$ year of studies. The same happened in the University of Thessaloniki. Then, first in the University of Thessaloniki in 1953 and afterwards in the University of Athens in 1967, the study of economics and political science were separated from law studies and autonomous departments of Economics and Political Science were created. Finally, first in the University of Athens in 1972 and then in other universities, economic and political science studies were separated and autonomous relevant departments were created.

A third feature was that Greek university economics as well as the whole economist community were in the beginning influenced mainly from Germany and France rather than England (Psalidopoulos (1999), p.173). This influence, as Psalidopoulos (1999: 184-5) accurately points out, ended in 1970-71 with the realignment of the Greek system with the by then dominant in economics Anglo-Saxon paradigm. However, the notso-short-lived Franco-German influence equipped Greek economists with a broader and more polyphonic perspective than the already ascending in the Anglo-Saxon world neoclassical one. For example issues of multi- 
disciplinarity and emphasis on a social perspective in economic analysis were strong even when they had been purged elsewhere. Of particular importance was the influence that the German Historical School yield as well as the role of a significant Greek economist of the 1920s and 1930s, A. Andreades (see Psalidopoulos (1999: 170-1). The German Historical School, despite its many shortcomings, paid emphasis on social conditions and thus avoided the separation of economic from social relations that neoclassicism institutes. On the other hand, A. Andreades took an eclectic perspective in economics; particularly between classical Political Economy, German Historical School and neoclassicism. Of course, there were some prohibited scientific areas. Marxism was excluded from academic studies although it was known to several academic economists (e.g. A. Sideris, D. Kalitsounakis - see Psalidopoulos (1999: 172)) and covered in academic journals (for example in the influential Archive of Economic and Social Sciences) $)^{3}$. This had to do with the fear that the workers' movement instilled to the bourgeois class and the persistent attempts of the latter to suppress it.

These national specificities of the Greek economist community marked the way Political Economy was defined. In the beginning - as indeed elsewhere - all academic chairs in economics were branded as 'Political Economy'. Very slowly there was a diversification and some specialized chairs were created (e.g. Public Economics). However, most of the basic chairs belonged to 'Political Economy'. On the other hand, under the rubric 'Political Economy' different meanings were hidden. In the beginning they denoted the perspective of Classical Political Economy and also that of the German Historical School. As such it laid emphasis on social relations and studied economic relations as part of the societal web. Neoclassicism started to make inroads in the 1930s. Formally it was taught within the auspices of Political Economy and, at the same

\footnotetext{
3 Two were the main academic economic journals: the Archive of Economic and Social Sciences (edited by D. Kalitsounakis) and the Review of Social and Public Economics (edited by X. Zolotas and A. Aggelopoulos). The first covered the whole spectrum of the social sciences (and not only economics) and his editor studied meticulously the Classical Political Economy. On the other hand, the Review of Social and Public Economics focused exclusively on economics with X. Zolotas representing liberal views and A. Aggelopoulos state interventionist views.
} 
time, it did not enjoy an unequivocal dominance. On the contrary, the ascendance of theories of planned economy - either of the Marxist type adhered by the young then the Soviet Union or of the 'state-socialist' type that the newer German Historical School advocated - together with the increased influence of economic state interventionism during the intra-war period inhibited significantly the spread of neoclassicism. Even doyens of liberalism (e.g. X. Zolotas ${ }^{4}$ ) flirted sometimes with socialist or quasisocialist economic ideas. It was only after the $2^{\text {nd }}$ World War that the grip of neoclassicism became firm in Greek economics. Again the general rubric 'Political Economy' was conserved but its content changed: now it was solely Marginalism. This nearly schizophrenic situation continued till the 1970s when slowly the chairs on general economic theory were changed from 'Political Economy' to 'Economics'. This process was part of the aforementioned purge of the Greek specificities and the realignment with the by then dominant Anglo-Saxon academic paradigm.

Of course, political and social conditions influenced this changing landscape. The realignment with the Anglo-Saxon paradigm stemmed from the development of Greek capitalism and its closer ties with the dominant Anglo-Saxon countries - first with the UK and after the $2^{\text {nd }}$ World War with the US. Thus neoclassicism became dominant and the type of standardization of the internal organization of economic science decoupled from the Franco-German perspectives and followed the Anglo-Saxon model ${ }^{5}$. The creation of the Centre for Economic Research (known as KEPE) played a significant role in that. This process evolved for good after the 1960s and it was promoted by both the Right and the Centre and Centre-Left in Greek politics. On the other hand, the Left remained - particularly after the Civil War of 1946-9 - excluded from the academia and literally persecuted ${ }^{6}$. Thus it had no actual influence on

\footnotetext{
$4 \mathrm{X}$. Zolotas was a famous Greek economist with a long-standing influence who became also prime minister for a limited period in the early 1990s.

5 Psalidopoulos (1999) gives a detailed and lucid account of this transformation, particularly in the chapter 'Economic Science in Greece, 1944-1967: From national specificities to the Anglo-Saxon paradigm'.

6 For example, even a prominent economist and member of a wealthy industrialist family, A. Aggelopoulos, who had participated in the communist-led Resistance against the Axis occupation was thrown out of the university.
} 
academic debates although it mastered a considerable influence outside it and popularized its ideas more systematically than the dominant trends ${ }^{7}$.

There is however an interesting point in this post-war era. Political Economy as a rubric was brushed aside but at the same time - particularly in the 1960s - Keynesianism started making significant inroads in the Greek economist community. Under its wings, shyly in the beginning, more radical problems started to appear. Thus the brushing aside of the rubric coincided with the emergence of approaches that can today classified as Radical Political Economy. This development was not curious. In the Anglo-Saxon world, after the war, Keynesianism had become the new orthodoxy and this was communicated to Greece by the economists that were trained abroad and returned to the country afterwards. The Keynesian dominance with its heretical (for neoclassicism) views on state economic intervention, demand, money and unemployment facilitated the emergence of more radical perspectives. Thus not only radical Keynesian approaches but also classical and Marxist Political Economy perspectives were reinvigorated. These began to trickle down to Greece despite the repressive political environment. In fact the pre-dictatorship period of relaxation of this environment facilitated this trickle down. Thus, views today classified as Political Economy began to appear in Greece without however using the very term in a stricter form.

The military dictatorship of 1967-74 suspended this process while the realignment while the Anglo-Saxon model continued even more forcefully. During its reign, the standardization of economics and its clear-cut separation from the other social sciences (through the creation of autonomous Economics departments) continued but radical views were again prohibited. It was only after the fall of the dictatorship that the aforementioned process began again. The radicalization of the Greek society and the return of academics who have worked abroad - many of whom had fled the dictatorship and opposed it actively - reinforced it.

7 The scientific journal Antaios was instrumental in elaborating and publicizing the economic views of the Left in the post-civil war period. 
The academic community was restructured, fresh views were introduced and the old academic apparatus was brushed aside (and purged to a rather small extent from those who had unabashedly co-operated with the military junta). The newfound air of freedom led to the flourish of radical perspectives. Another crucial new feature was that Marxist Political Economy was 'legalized' and entered the academic community.

These developments led to a change of the understanding of Political Economy. Within this new boundary, they were enlisted all these theories and currents that stress the social nature of economic relations and proceed to study them accordingly as opposed to the neoclassical a-social and individualist perspective. Under this new banner Marxist Political Economy, the revival of Classical Political Economy (particularly in the form of NeoRicardianism), radical post-Keynesianism and institutionalism spread in the Greek economist community and acquired a significant foothold in the academia. Thus, the term 'Political Economy' started to be used again in academic appointments and scientists working within this perspective began to be accepted in specialized scientific fields (an almost non-go area previously).

This conception of the term 'Political Economy' continued to hold till the 1990s. However, soon disconcerting signs appeared. Neoconservatism in Greece became dominant with a significant time-lag (compared to the West). Whereas in the West neoconservatism was dominant from the early 1980s, in Greece it reigned by the early 1990s. This neoconservative onslaught gripped the Greek university as well.

Neoconservatism in higher education began in the late 1980s. In the beginning it was concealed behind 'innocent' changes of supposedly technical nature. In the case of economics' departments this took the form of the creation of several new departments that fell broadly within the sphere of economics ${ }^{8}$. However, contrary to the old general economics departments the new ones were extremely specialized in scope. In essence,

8 For a detailed presentation see Petralias (1999). 
these new departments were more technocratic and thus, silently, Political Economy was pushed aside. At the same time the crisis in the relation between the university in general (and the economics departments in particular) and the labour market had erupted for good. After a golden era of rapid development - from the mid-1950s till the 1973-4 - Greek capitalism entered a period of structural crisis. The Greek university has expanded during the previous golden era because there was an urgent need for educated personnel and particularly scientific wage labor. This, in turn, facilitated possibilities of social ascendancy for middle and lower classes. Thus the Greek university became a truly mass university with limited class barriers.

The arrival of the 1973-4 crisis disrupted these links. A first victim was the old traditional general economics departments: their degrees were considered not sufficiently marketable and thus not securing getting a good job. On the contrary, the new specialized and more technocratic departments were considered as better equipped for this. It is characteristic that the two older economics departments (those of the University of Athens and Thessaloniki) were overtaken by newer departments - coming from older professional schools - as the first choices of new entrants. Several of these newer departments were actually quite old - though not older from the two aforementioned ones - but were not part of the university system in the beginning. They became part of it later on and in the 1980s acquired the formal title "university'. These were older than the other new specialized of the 1980s but at the same time were keener than the old traditional departments to follow the new dominant trends. Their ascent was founded in the combination of having an 'air' of tradition by not being newly-found and at the same time conforming willingly to the new social, economic and political prerogatives. Thus they eagerly transformed internally by both creating new specialized and technocratic departments and making their older economics departments more orthodox. This situation was further aggravated in the 1990s when neoconservatism became even stronger

9 Thus, the Athens School of Economic and Trade Science was renamed Athens University of Economics and Business and the Higher Industrial Schools of Thessaloniki and Piraeus were renamed as Universities of Macedonia and Piraeus respectively. 
and started to promote its intellectual core more openly. This was coupled with a greater turn towards quantitative techniques, empirical studies (with limited or no economic analysis) or mathematical modeling (of an extremely unrealistic abstract nature).

This neoconservative turn affected through two paths the conception and the status of Political Economy. The first path was expressed by some limited attempts by neoclassicism to hijack the area of Political Economy through a short-lived attempt to promote the so-called New Political Economy and particularly Public Choice theory. In both cases it was argued that the consideration of political aspects - but within an individualist framework and without the consideration of social aspects as such - legitimized the use of the term. In other words, economic analysis could speak about lobbies and institutions but not about social classes and class struggle. Thus, this view was projected as the new meaning of the term. Not only this but even the exclusion of Marxist, Classical and Institutionalist political economic perspectives from the area of Political Economy was preached since they were deemed as 'dated' and 'sociological'; and thus belonging to the pre-history of economic science which has no place in a modern university. This whole endeavor falls completely into the new phenomenon of 'economics' imperialism' - i.e. the recent attempt by neoclassicism to conquer scientific fields that were previously non-go areas for $\mathrm{it}^{10}$. It is interesting to note that this hijacking attempt was not based on the work of the founders of marginalist analysis (Walras, Jevons, Bohm Bawerk, Clark etc.) who indeed tackled issues of Political Economy, but from a subjectivist utilitarian viewpoint. On the contrary, in this new neoconservative attempt even these perspectives were absent and Political Economy was redefined as simply the analysis of political issues from a marginalist perspective. However, these far-fetched and rather extravagant attempts did not succeed. The causes of this failure are two. First, there was still significant resistance within academia but

10 The case of 'economics' imperialism' was exclaimed by Lazear in many papers (e.g. Lazear (2000)) and criticized accurately by Fine (e.g. Fine (2007)). 
also the students against neoconservatism. Second, neoconservatism - in the end - preferred to proceed directly to the purge of Political Economy instead of trying to liquidate it from within.

The second - and dominant - path was an outright purge of Political Economy from the Greek university. It actually blocked its postdictatorship spread and inaugurated once again systematic attempts not only to contain it but actually to curtail it. Hence, the number of new academic appointments in Political Economy was curtailed tremendously and even older appointments changed or were not renewed. This move was supported - and to a significant degree instigated - by the educational policies of all the recent Greek governments.

To summarize, in the beginning of Greek academic economics (i.e. in the end of the $19^{\text {th }}$ century) the term 'Political Economy' was used extensively and it was understood as general economic theory. In essence, it followed the Classical Political Economy tradition but also, to a significant extent, the German Historical School. As such it laid a certain emphasis on the social dimension of economic relations. On the other hand, Marxist Political Economy was almost completely excluded. Neoclassicism started to make significant inroads from the 1930s and onwards but this was checked by the strength of the economic theories that stressed the role of the state in the intra-war period. During this whole period the rubric 'Political Economy' was treated as synonymous with general economic theory and even purely neoclassical approaches used the title. Beginning before the $2^{\text {nd }}$ World War and accentuated afterwards the term 'Political Economy' started to be displaced by the term 'Economics' and 'Economic Theory' (or Economic Analysis). In the late 1960s, while the marginalization of the term continued, there appeared - under the auspices of Keynesianism radical theories that can today be classified as Radical Political Economy. During the period of the military dictatorship these radical perspectives were again repressed and the marginalization of Political Economy continued. After the fall of the dictatorship a new conception of Political Economy was established as the social understanding of economic relations. 


\section{THE POSITION of POLITICAL ECONOMY in THE ACADEMIC SYLLABI and in the TEACHING PROGRAMS of THE SECONDARY EDUCATION}

The changing scientific and academic landscape that was presented above is closely related to the position that Political Economy holds in the curricula of university departments and in the teaching programs of the secondary education (since the introduction of economic courses in the later).

From the beginning of the standardization of the economics curricula (and the turn towards the Anglo-Saxon academic paradigm) after the $2^{\text {nd }}$ World War and till the end of the 1970s economic studies were dominated by a rather arcane version of neoclassicism. Keynesian theory was introduced in the 1960 s - in the form of the Hicksian post-Keynesian neoclassical synthesis. Some more radical Keynesian perspectives were introduced in the late 1960s but this trend was interrupted by the strict control that the military dictatorship exercised on the universities. Thus, studying economics from a social perspective - i.e. Political Economy as such was prohibited. At the same time the principles' courses - and usually the textbooks that accompanied them - were branded as 'Introduction to Political Economy'. The same happened with many of the university chairs of that time. The explanation of this contradiction is quite simple. The Greek university system from its very constitution followed Western trends in academia but with a sometimes considerable time-lags. Hence, from the 1960s and onwards economics departments, while purely neoclassical in essence, kept the outward appearance of the older tradition in economics (i.e. that of Political Economy).

This situation started to change in the late 1970s and early 1980s, after the fall of the military junta and the liberalization of the university. The combined impacts of the radicalization of the Greek society, the influence of the student movement (which played a crucial role in the anti-dictatorship struggle), the purge of the academics that energetically supported the dictatorship and the return of a significant number of Greek academics who fled the country during the dictatorship had a rejuvenated effect on economic studies. Academic curricula were reorganized drastically and more radical approaches were introduced. Political Economy proper was 
introduced and indeed held a prominent influence in the academic syllabi. Marxist Political Economy, as part of the Political Economy tradition, was for the first time introduced both as part of Political Economy courses and as an autonomous course.

In the mid-1980s there was another important development. In 1984 an economics course was for the first time introduced in the secondary education. It was taught at the $6^{\text {th }}$ (and last) class of the secondary education and was designed to provide elementary knowledge of economics at a beginner's level particularly for those students that aimed to enter an economics department. Later, in 2000, another economics course was introduced at the $4^{\text {th }}$ class of the secondary education. Thus, from the mid1980s and onwards, the new entrants in the economics departments had some knowledge of economics. Another major development took place in 1993 when the subject of Political Economy replaced that of Sociology as one of the courses of the entrance exams for the economics departments ${ }^{11}$. This change was particularly important - and sparked a row with the teachers of Sociology - because of the crisis of the educational system that was mentioned before. To put it simply, as the economic and social conditions of the middle and lower classes worsened there was even more pressure for their off-springs to enter the university as a way of social ascent. This made particularly the last classes of the secondary education mere appendages to the university entrance exams. Hence, taught courses that were not among those examined fell into obscurity and lacked attention. That was the case with the economics courses till the 1993, which meant that till then very few entrants to economics departments had any previous knowledge of economics. This changed after the 1993 and thus academic curricula had to be revised accordingly.

The introduction of economics courses in the secondary education posed the question of the theoretical content of these courses. In the beginning, the economics courses of the secondary education fell within the auspices

11 In Greece the entrance to the university passes through a national examination process, which is differentiated in several broad areas (e.g. Medicine, Law, Economics, Engineering etc.) and which is conducted under the auspices of the Ministry of Education. In each area the standards are universal and set by the ministry. 
of Political Economy. Thus, they taught both the social aspects of economic relations and the existence of contending approaches within economic theory. At that time there was an overwhelming consensus within the educational community - academic and otherwise - on this issue but also within the Greek society in general. This overwhelming consensus is clearly indicated in the proceedings of a conference on 'Political Economy and the liaison between Mid and Higher Education' organized by the older Greek economics department, the Greek Economic Chamber and the Greek Federation of Secondary State School Teachers in Athens in 1995 (see Union of Economist Teachers of the Secondary Education (1995)). Even the more conservative approaches did not dispute the necessity of studying economics from a social perspective nor the branding of the courses as 'Political Economy'12. Thus, the first textbook was titled 'Political Economy' and presented both Political Economy and Neoclassical theory. Another textbook replaced it in 1992 which also was titled Political Economy and presented both Political Economy and Neoclassical theory.

As said before, the neoconservative tide started to affect the Greek educational system with a time-lag. This affected the position of Political Economy in both the academic syllabi and the teaching programs of the secondary education. Hence, from the mid-1990s and onwards systematic attempts took place to marginalize Political Economy.

In academic syllabi courses of Political Economy (and Marxist Political Economy either as part of it or as a distinct subject) were reduced. It is indicative that almost all the nine purely economics departments (in the universities of Athens, Thessaloniki, Macedonia, Crete, Piraeus, Patras, Ioannina, Thessaly and AUEB) had before the mid-1990s a compulsory course on Political Economy at an introductory level. These introductory

12 There was a minor disagreement not with the essence of Political Economy as such but for renaming it as Social Economics on the grounds that this is more intuitive today. However, even this modification was not espoused. It is also indicative that there was also another proposal for the creation of a special body of secondary education teachers of social sciences who would teach economics, politics and sociology. This shows how strong was the emphasis, at that time, on the links between the social sciences. 
courses were usually coupled with either a compulsory or an elective course on Marxist Political Economy and also with several specialized courses in which Political Economy occupied a significant part (e.g. Development). After the mid-1990s compulsory introductory courses were reduced to 4 out of the 9 and some of the elective courses were eliminated. At the same time, the presence of Political Economy in specialized courses was also reduced in many cases.

The same process took place in the teaching programs of the secondary education. Thus, in 1993-4 a new textbook was introduced that kept the title 'Political Economy' (with the subtitle Microeconomics-Macroeconomics) but its content was only neoclassical theory. This was replaced in the same year by another textbook with the title 'Economic Theory' whose content was also only neoclassical theory. This was again replaced in 2003 by another textbook under the title of 'Principles of Economic Theory' (taught till today) presenting solely the neoclassical perspective. Curiously enough the textbook for the $4^{\text {th }}$ class of the secondary education has remained the same and still covers aspects of Political Economy.

In a nutshell, the neoconservative turn took place in the Greek educational system with a noticeable time-lag from the 1993 and afterwards. Since its launch it affected the position of Political Economy in both the secondary and the higher education by marginalizing it to a great extent. This process holds till the beginning of the $21^{\text {st }}$ century. However, the onset of the fourth global capitalist crisis (the 2008 economic crisis), the subsequent 2010 eurozone crisis (and the Greek 2010 economic crisis that is part of it) create serious problems to the mainstream dominance. But the new landscape is still far from clear. 


\section{REFERENCES}

[1] Fine B. (2007), 'The Historical Logic of Economics Imperialism and Meeting the Challenges of Contemporary Orthodoxy: Or Twelve Hypotheses on Economics, and What is to Be Done', Paper presented at EAEPE Conference, 1-3 November 2007, Porto, Portugal.

[2] Lazear E. (2000), 'Economic Imperialism', Quarterly Journal of Economics 115(1): 99-146, previously National Bureau of Economic Research, Working Paper no 7300, 1999.

[3] Petralias N. (1999), 'Changes in the departmental structure of the Greek universities and the specializations of the degrees awarded: 1982/83 -1998/99' in the volume of the conference 'Prospects and Future of Social Sciences in Greece', Dept. of Sociology, University of Crete - in Greek.

[4] Psalidopoulos M. (1999a), Political Economy and Greek Intellectuals, Athens: Typothito - in Greek.

[5] Schumpeter J. (1954), History of Economic Analysis, New York: Oxford University Press.

[6] Union of Economist Teachers of the Secondary Education (1995), Political Economy and the liaison between Mid and Higher Education, volume of the conference organized by the Dept. of Economics of the University of Athens, the Greek Economic Chamber and the Greek Federation of Secondary State School Teachers, Athens 1995 - in Greek.

[7] Kalitsounakis D. (1940), '20 years Archive', Archive of Economic and Social Sciences, no.A.

[8] Psalidopoulos M. (2000), 'Institutional constraints and the internationalization of economics: The case of Greece' in A.W. Coats (ed.) The Post-1945 Development of Economics in Europe, London: Routledge.

[9] Psalidopoulos M. (1990), 'Forms of economic thought in Greece, 1936-1940' in Fleischer H. \& Svoronos N. (eds.), Greece 1936-1944: Dictatorship - Occupation - Resistance, Athens: Gutenberg (in Greek). 